\title{
INCIDENCE OF CALF MORBIDITY AND MORTALITY AT CIG DAIRY FARMS OF MUKTAGACHA UPAZILA IN MYMENSINGH DISTRICT
}

\author{
M. N. Islam ${ }^{1}$, A. K. M. A. Rahman ${ }^{1}$, M. S. Nahar ${ }^{2}$, A. Khair ${ }^{1}$ and M. M. Alam ${ }^{1 *}$ \\ ${ }^{1}$ Department of Medicine, Faculty of Veterinary Science, Bangladesh Agricultural University \\ Mymensingh-2202, Bangladesh \\ ${ }^{2}$ Veterinary surgeon, Department of Livestock Services, Bangladesh
}

\begin{abstract}
Calf morbidity and mortality are important causes of economic losses on dairy farms worldwide. An investigation on the incidence of calf morbidity and mortality was conducted on 92 purposively selected CIG (Common Interest Group) dairy farms in Muktagacha upazila of Mymensingh district. A total of 119 calves from the farms were longitudinally followed from August 2014 to November 2014 for major health problems. Representative fecal samples from diarrhoeic calves were tested to identify gastro-enteropathogens associated with diarrhea by rapid detection test kit (Bio K 306). The overall incidence risk of morbidity and mortality were $56.17 \%$ and $6.29 \%$, respectively. The most frequent disease syndrome was diarrhea with incidence risk of $34.82 \%$ followed by navel ill $(7.22 \%)$ and pneumonia $(6.29 \%)$. In addition, fever, arthritis, pica and foot and mouth disease were encountered. The main causes of death in calf were pneumonia (3.739\%) and FMD (1.78\%). A variety of infectious agents are implicated in calf diarrhea and co-infection of multiple pathogens is not uncommon. The overall prevalence of microorganisms associated with diarrhea was $69.2 \%$ in which Clostridium perfringens was the highest (38.5\%) within the first month of age. The prevalence of Cryptosporidium spp within first month of age was $7.7 \%$. In this study, mixed infection with Clostridium perfringens and Cryptosporidium spp or Corona virus was found in $7.7 \%$ of diarrheic calves within 10 days of the age. It is now established that calf morbidity and mortality are an important limiting factors for the success of modern dairy farms and accordingly vigorous and comprehensive research should be taken to minimize the problem.
\end{abstract}

Key words: Incidence risk, Calves, Morbidity and Mortality, Diarrhoea

\section{INTRODUCTION}

Bangladesh is agriculture based densely populated country and livestock is an essential component of the rural economy and the livelihood of the subsistence farmers (Islam et al., 2006; Hossain et al., 2013). The cattle population in Bangladesh is about 24.5 million which is about $1.79 \%$ of the world and $5.47 \%$ of Asia cattle population (FAO, 2004). Number of cattle per livestock household is 3.5 and that of 0.94 for all household (BBS, 2002). According to Bangladesh Economic Review (2014) the total number of registered dairy farms is 6,06069 . The current production of milk and meats are inadequate to meet the current requirement and the deficits are 85.9 and $77.4 \%$ respectively. If 5\% GDP growth rate is considered then the current production of these commodities need to be increase 2.5 to 3.0 times by the year 2020 to feed the growing population in the country (National Livestock Development Policy, 2007).

The success of any breeding program as well as the future of the mini dairy farms depends upon the rate of survival of calf crop produced and accordingly calf morbidity and mortality are of great concern of dairyman, because most of the dairy farms are confronted with acute problems of calf morbidity \& mortality (Gitau et al., 2010; Wudu et al., 2008). Under modern dairy production in the developed world, the average length of time a cow stays in a milking herd is about four years and, therefore, $25 \%$ of the milking herd must be replaced each year. The calf mortality represents an irrefutable and irrevocable financial source of economic loss to the dairyman due to loss of the present value of the calf and loss of genetic potential for herd improvement (Debnath et al., 1990, 1995; Hossain et al., 1992; Samad et al., 2002). Calf mortality up to 12 months of age with estimate of $9 \%$ under rural (Debnath et al., 1990) and 13.4\% under a farm (Debnath et al., 1995) conditions have been reported in Bangladesh.

*Corresponding e-mail address: asamahbub2003@yahoo.com

Copyright $@ 2015$ Bangladesh Society for Veterinary Medicine

All rights reserved 0324/2015 
Dairy industry is a crucial component of agro-based economy for a country like Bangladesh (Islam et al., 2006) and Bangladesh has a suitable environment for cattle but dairy industry has not been developed satisfactory due to various limiting factors. Calf morbidity and mortality is the principle factor of them. It has been the subject of much research in the last three decades worldwide but very limited works have been made from Bangladesh. Most of the inland reports based on hospital and /or farm records and pathological findings but there seems to be no reports or paucity of reports on etio-epidemiological factors associated with calf morbidity and mortality in Bangladesh. Infectious diseases have also been recognized as one of the important factors in the calf production worldwide and calf diarrhea is the most important disease problem in the young calf (Heinrichs and Radostits, 2001; Trence, 2001; Wudu et al., 2008).

The incidence risk of diarrhea in calves varies from $20.05 \%$ to $52.51 \%$ (Samad, 2008; Wudu et al., 2008; Megersa et al., 2009; Malik et al., 2012) but very few such reports have been made under local conditions. In view of above situation, the present study was conducted to study the incidence risk of diseases/or disorders of calf in CIG dairy farms. The etiological agents causing calf diarrhea associated with morbidity and mortality was also addressed.

\section{MATERIALS AND METHODS \\ Experimental design:}

CIG (Common Interest Groups) dairy farms have been selected from Muktagacha upazila of Mymensingh district. CIG farms are located in Bashati, Kashimpur, Kheurajani, Taraty, Borogram and Kumargata union of Muktagacha. A total of six dairy CIG in Muktagacha and each CIG consist of 20 farmers. At present 105 CIG dairy farm have been operating where 92 farmers have calves and 15 farmers have no cattle. Number of total cattle was 366 where cows, heifers, bulls and calves were 134, 49, 64 and 119, respectively. Calves from day old to 1 year of age were included in this study. A longitudinal study for calf morbidity and mortality was carried out. The sampling units (calves) were identified individually and monitored throughout the study period. The questionnaire survey was also conducted during the study period to collect herd level and calf level data.The study was conducted during the period from August 2014 to November 2014.

\section{Data collection}

The morbidity was defined with recognizable clinical findings and mortality as death of calves. Individual calf records were prepared using a format when a calf joined the study cohort. In the process of monitoring, calves were visited every two weeks interval.

Calf morbidities encountered during the monitoring period were categorized in eight disease conditions/syndromes based on their clinical signs. These were diarrhoea, navel ill; pneumonia, fever, arthritis, foot and mouth diseases (FMD), pica and miscellaneous cases were skin lesions, weakness, anorexia and bloat.

\section{Sample collection for identification of infectious agents associated with calf diarrhea}

A total of 44 fecal samples were collected from untreated dirrhoeic calves soon after onset of diarrhea to detect the agents associated with calf diarrhea. About ten grams of feces was collected from rectum in separate sterile container, kept at an ice cold condition and transported quickly to laboratory. A total of 13 representative fecal samples from 44 diarrhoeic calves were tested for detection of Escherichia coli, Clostridium perfringens, Rotavirus, Corona virus and Cryptosporidium spp. Rainbow Calf scours 5, BioX Diagnostics, Belgium test kits were used to perform the tests.

\section{Data Analysis}

Data was entered in MS excel 2010 \& transferred to R Statistical software ( $R$ foundation for Statistical Computing, Vienna, Austria) for descriptive statistics and incidence analysis was done by the methods of Martin et al. (1987).

\section{RESULTS}

\section{Descriptive statistics}

This study included 105 dairy herds and the herds consist of $61.0 \%$ small (1-3 cattle) and 39.0\% medium (>3 cattle) holder farms. About $95.7 \%$ farmers had 1 to 2 calves and $76.2 \%$ farmers had kacha floor of their cattle shed. A brief description of CIG dairy farmer's is shown in Table 1. 


\section{Morbidity and mortality}

To determine the incidence of diseases and disorders, 119 calves were observed for four months. The incidence of different diseases and disease conditions/syndromes was shown in Table 2. The overall incidence risk of calf diseases was $56.17 \%$. The calf diarrhea was found to be the leading cause of calf morbidity with incidence risk of $34.82 \%$, followed by naval ill $(7.22 \%)$. The total number of miscellaneous case was seven including two skin lesions, one weakness, two anorexia and two bloat. The mortality of calf associated with different diseases was shown in Table 3. The results of our findings revealed that the incidence risk of mortality was $6.29 \%$.

Table 1. Brief description of the CIG dairy farmers at Muktagacha upazila included in this study

\begin{tabular}{|c|c|c|}
\hline Unit & Number & Percentage \\
\hline No. of total farmers & 120 & - \\
\hline Farmers having cattle & 105 & 87.5 \\
\hline Farmers without cattle & 15 & 12.5 \\
\hline Farmers having calves & 92 & 87.6 \\
\hline Farmers without calves & 13 & 12.4 \\
\hline \multicolumn{3}{|l|}{ Area } \\
\hline Bashaty & 20 & 19.0 \\
\hline Kasempur & 17 & 16.2 \\
\hline Kheurajani & 17 & 16.2 \\
\hline Borgram & 17 & 16.2 \\
\hline Taraty & 20 & 19.0 \\
\hline Kumargata & 14 & 13.3 \\
\hline \multicolumn{3}{|l|}{ Education label } \\
\hline Home & 50 & 47.6 \\
\hline Primary & 29 & 27.6 \\
\hline Secondary & 22 & 21.0 \\
\hline College & 4 & 3.8 \\
\hline \multicolumn{3}{|l|}{ Occupation } \\
\hline Day labour & 6 & 5.7 \\
\hline Crop cultivation & 64 & 61.0 \\
\hline Livestock Farming & 32 & 30.5 \\
\hline Business & 3 & 2.9 \\
\hline \multicolumn{3}{|l|}{ Production purpose } \\
\hline Own consumption & 28 & 26.7 \\
\hline Mixed & 77 & 73.3 \\
\hline \multicolumn{3}{|l|}{ Land } \\
\hline Up to 1 acre & 90 & 85.7 \\
\hline$>1$ acre & 15 & 14.3 \\
\hline \multicolumn{3}{|l|}{ Monthly total income } \\
\hline Up to tk. 15000 & 28 & 26.7 \\
\hline$>$ tk. $15000-30000$ & 51 & 48.6 \\
\hline$>$ tk. 30000 & 26 & 24.8 \\
\hline \multicolumn{3}{|c|}{ Monthly income from livestock } \\
\hline Up to tk. 8000 & 69 & 65.7 \\
\hline$>$ tk. $8000-16000$ & 19 & 18.1 \\
\hline$>$ tk. 16000 & 17 & 16.2 \\
\hline
\end{tabular}




\section{N. Islam and others}

Table 1. Brief description of the CIG dairy farmers at Muktagacha upazila included in this study (Cont.)

\begin{tabular}{lll}
\hline Housing & & \\
$\quad$ Brick floor & 25 & 23.8 \\
$\quad$ Kacha floor & 80 & 76.2 \\
Shed disinfection & 1 & \\
$\quad$ Daily & 7 & 1.0 \\
Weekly & 34 & 6.7 \\
Monthly & 63 & 32.4 \\
Not done & & 60.0 \\
Herd size & 64 & 61.0 \\
Up to 3 & 41 & 39.0 \\
$>3$ & & \\
No. of calf & 88 & 95.7 \\
Up to 2 & 4 & 4.3 \\
$\quad>2$ & & \\
Weaning time & 66 & 71.7 \\
$\quad$ Up to 10 days & 26 & 28.3 \\
$>10$ days & & \\
Age of 1st deworming & 40 & 43.5 \\
$\quad$ Up to 45 days & 52 & 56.5 \\
\hline 45
\end{tabular}

Table 2. The incidence of different diseases and disease conditions/syndromes in calves

\begin{tabular}{llllll}
\hline $\begin{array}{l}\text { Diseases } \\
\text { condition/syndromes }\end{array}$ & $\begin{array}{l}\text { No. of } \\
\text { cases }\end{array}$ & $\begin{array}{l}\text { Calf months } \\
\text { at risk }\end{array}$ & $\begin{array}{l}\text { Per calf } \\
\text { month }\end{array}$ & $\begin{array}{l}\text { Incidence rate } \\
\text { True rate (4 calf } \\
\text { month at risk) }\end{array}$ & Incidence risk (\%) \\
\hline Dirrhoea & 44 & 411.0 & 0.107 & 0.428 & 34.82 \\
Naval ill & 8 & 429.0 & 0.019 & 0.076 & 7.22 \\
Pneumonia & 7 & 429.5 & 0.016 & 0.065 & 6.29 \\
Fever & 5 & 430.5 & 0.012 & 0.046 & 4.50 \\
Arthritis & 4 & 431.0 & 0.009 & 0.036 & 3.63 \\
Pica & 4 & 431.0 & 0.009 & 0.036 & 3.63 \\
FMD & 2 & 432.0 & 0.005 & 0.019 & 1.98 \\
Miscellaneous cases & 7 & 429.5 & 0.016 & 0.065 & 6.29 \\
Morbidity & 81 & 392.5 & 0.206 & 0.825 & 56.17 \\
\hline
\end{tabular}

Table 3. The mortality of calf associated with different diseases

\begin{tabular}{llllll}
\hline Cause of death & $\begin{array}{l}\text { No. of } \\
\text { death }\end{array}$ & $\begin{array}{l}\text { Calf months at } \\
\text { risk }\end{array}$ & $\begin{array}{l}\text { Incidence rate } \\
\text { Per calf } \\
\text { month at risk }\end{array}$ & $\begin{array}{l}\text { True rate }(4 \text { calf } \\
\text { month at risk })\end{array}$ & $\begin{array}{l}\text { Incidence risk } \\
(\%)\end{array}$ \\
\hline Pneumonia & 4 & 427.5 & 0.009 & 0.038 & 3.73 \\
FMD & 2 & 431.0 & 0.005 & 0.018 & 1.78 \\
Miscellaneous cases & 1 & 429.0 & 0.002 & 0.009 & 0.90 \\
Mortality & 7 & 429.5 & 0.016 & 0.065 & 6.29 \\
\hline
\end{tabular}




\section{Pathogens associated with diarrhea in calf}

A total of 13 fecal samples from 44 diarrhoeic calves were tested by rapid detection test (Bio K 306) to identify pathogens associated with diarrhea in calves. A positive sample of both Clostridium perfringens and Cryptosporidium spp. (A); Clostridium perfringens (B), and Coronavirus (C) were shown Fig. 1.
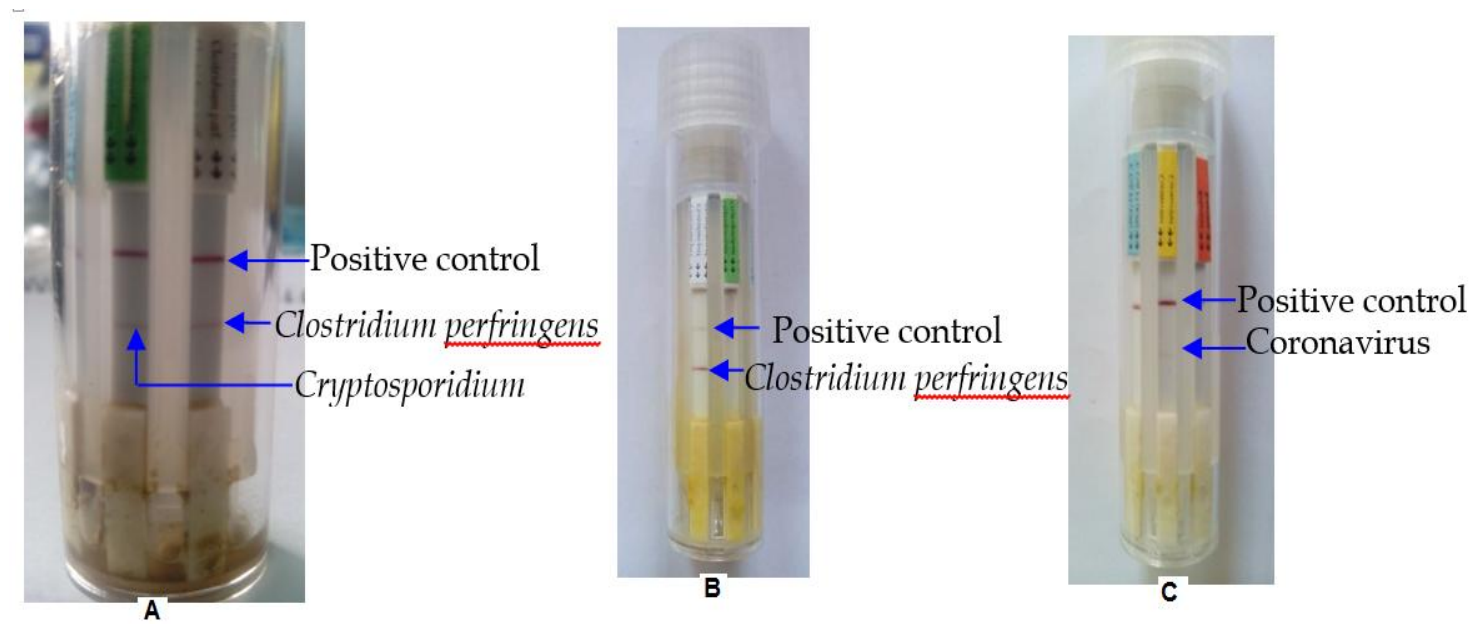

Fig.1. Rainbow calf Scour 5 (Bio K 306) test kit results

The prevalence of infectious diarrhea in calves was $69.2 \%$ and shown in Table 4 .

Table 4. Prevalence of infectious diarrhea in calves $(n=13)$

\begin{tabular}{llll}
\hline Age (days) & Name of organisms & Positive & Prevalence (\%) \\
\hline $13-30$ & Clostridium perfringens & 5 & 38.5 \\
4 & Cryptosporidium spp & 1 & 7.7 \\
10 & Clostridium perfringens + Cryptosporidium $\mathrm{spp}$ & 2 & 15.4 \\
10 & Clostridium perfringens + Corona virus & 1 & 7.7 \\
Overall positive & & 9 & 69.2 \\
\hline \multicolumn{2}{c}{$\mathrm{n}=$ Sample size } & &
\end{tabular}

\section{DISCUSSION}

Calf morbidity and mortality are the major constraints of dairy farming system. We have estimated the incidence of calf morbidity and mortality in some selected dairy farms of Muktagacha upazila of Mymensingh district in Bangladesh. The overall incidence risk of calf diseases was 56.19\%. Similar observations were also made by other authors (Wudu et al., 2008; Ferede et al., 2014). The overall mortality of calf diseases was $6.29 \%$ which was lower than many previous reports like $9.3 \%, 71.1 \%$ and $30.7 \%$ of Megersa et al. (2009), Hossain et al. (2013) and Ferede et al. (2014), respectively. This difference might be due to better health management. It could be mentioned that $95.7 \%$ farmers had only 2 or less than 2 calves in CIG farms and accordingly farmers have given sufficient time for nursing the sick calves which might be the reason of lower mortality.

The calf diarrhoea was the leading infectious cause of calf morbidity. Our finding was in agreement with the previous findings of some authors (Trence, 2001; Wudu et al., 2008). The incidence risk of calf dirrhoea was $34.82 \%$, which was in agreement with other authors (Megersa et al., 2009 and Malik et al., 2012). In our study, the incidence risk of navel ill was 7.2\%, which squares with the report of Ferede et al. (2014). 
However Wudu et al. (2008) reported lower incidence risk (3.7\%) of navel ill than our finding. In this study, about $76.2 \%$ farms had kacha floor and they did not cut umbilical cord just after delivery and did not use antiseptic to prevent navel infection. In fact, farmers didn't know the benefit of this nursing towards newborn calf and that ignorance might be lead to the increase in the incidence risk of navel ill.

The incidence risk of morbidity and mortality for pneumonia were $6.29 \%$ and $3.73 \%$, respectively. Wudu et al. (2008) reported lower (4.9\%) but Ferede et al. (2014) reported higher (18.6\%) morbidity of pneumonia than our study. It was interesting to note that mortality risk due to pneumonia was very low $(3.73 \%)$ within the first six month of age in comparison to others who reported $15-38.75 \%$ mortality within the same age group (Samad, 2008; Hossain et al., 2013). Our study was conducted during the period of late rainy season and early winter season when the weather was not so cold, which might be the reasons for low incidence risk of mortality due to pneumonia. But these variables were not analyzed statistically.

The mortality risk for FMD was $1.78 \%$ in CIG dairy farm, which was supported by the report of Hossain et al. (2013). However, Debnath et al. (1995) showed that FMD contributes significantly to calf mortality even after regular vaccination. In our study area the many farmers introduced new cows of their farms from unknown source within first weeks of delivery which might be the reasons for outbreak of FMD in calves and causes mortality.

The incidence risk of fever was $4.5 \%$ in the study area. All the cases of fever were recorded within five to six month of age in which four was cross breed calves and one was indigenous calf.

The incidence risk of arthritis was 3.63\%, which was supported by other authors (Shiferaw et al., 2002; Wudu et al., 2008). It was very interesting finding of this study that the incidence risk of pica was $3.63 \%$. The factors responsible for this condition were not studied but all of the four affected calves were also suffering from internal parasites like fluke, nematode and protozoa.

The overall prevalence of microorganisms associated with diarrhea was $69.2 \%$ in which Clostridium perfringens was the highest $(38.5 \%)$ within the first month of age. This result was supported by Samad (2008) who reported that most cases of calf scours occur less than one month of age. Clostridium perfringens is ubiquitous in nature and also found in alimentary tract of healthy calves. In our study area farmers were not allowed adequate colostrums and milk of their calves which might be lead to increase clostridia infection. The prevalence of Cryptosporidium spp. infection within first month of age was 7.7\%, which was very low in comparison to the finding of Khair et al. (2014) who reported $24.49 \%$ in crossbred calves. It might be due to differences in the size of samples and animal husbandry practices between study areas.

We have observed mixed infection with Clostridium perfringens and Cryptosporidium spp. in $15.4 \%$ and Clostridium perfringens and coronavirus in $7.7 \%$ of diarrhoeic calves. The age of these calves were up to 10 days. Khair et al. (2014) and NADIS (2014) had also reported that cryptosporidiosis occurs within first month of age and corona virus infections cause diarrhea in calves up to 20 days. In our study area farmers were not allowed adequate colostrums and milk of their calves which might be lead to increase infectious dirrhoea in calves in early age.

In this study the incidence risk of calf morbidity and mortality found $56.17 \%$ and $6.29 \%$, respectively which is higher than the economically tolerable level. The present study also showed that calf diarrhoea was the predominant calf health problem responsible for the majority of calf illnesses. However, calf diarrhoea is a syndrome of great etiological complexity and major infectious causes involved. Further comprehensive and extensive study is recommended to identify the risk factors and etiological agents associated with calf morbidity and mortality.

\section{ACKNOWLEDGEMENTS}

The authors thank to The National Agricultural Technology Project (NATP) Phase-1, Department of Livestock Services, Ministry of Fisheries and Livestock, Government of the People's Republic of Bangladesh for funding of this research, 
Incidence of calf morbidity and mortality at CIG dairy farms

\section{REFERENCES}

1. BBS-Bangladesh Bureau of Statistics (2002). Statistics Year Book of Bangladesh, Ministry of Planning, Dhaka, Bangladesh.

2. Debnath NC, Sil BK, Selim SA, Prodhan MAM and Howlader MMR (1990). A retrospective study of calf mortality and morbidity on smallholder traditional farms in Bangladesh. Preventive Veterinary Medicine 9: 1-7.

3. Debnath NC, Taimur MJFA, Saha AK, Ersaduzzaman M, Helaluddin M, Rahman ML, Roy DK and Islam MA (1995). A retrospective study of calf losses on the central dairy cattle breeding station in Bangladesh. Preventive Veterinary Medicine 14: 43-53.

4. FAO (2004). Food and Agriculture Organization of the United Nations. Ministry of Fisheries and Livestock, Bangladesh, p. 65.

5. Ferede Y, Mazengia H, Bimrew T, Bitew A, Nega M and Kebede A (2014). Pre-weaningmorbidity and mortality of crossbred calves in Bahir Dar Zuria and GozamendistrictsofAmhara region, Northwest Ethiopia. Open Access Library Journal 1: e600.

6. Gitau GK, Aleri JW, Mbuthia PG and Mulei CM (2010). Causes of calf mortality in peri-urban area of Nairobi, Kenya. Tropical Animal Health and Production4 2: 1643-7.

7. Heinrichs AJ and Radostits OM (2001). Health and production management of dairy calves and replacement heifers. In: Radostits OM (editor.): Herd Health, Food Animal Production Medicine, $3^{\text {rd }}$ edition, W.B. Saunders Company, Philadelphia, USA. p. 333-395.

8. Hossain MI, Hossain MM, Hannan BMA, Kamal AHM, Mondal MMH and Wadud A (1992). Mortality of calves associated with gastro-intestinal helminthes infection. Bangladesh Veterinary Journal 9: 7-13.

9. Hossain MM, Kamal AHM and Rahman AKMA (2013). Retrospective study of calf mortality on Central Cattle Breeding and Dairy Farm (CCBDF) in Bangladesh. Eurasian Journal of veterinary Science 29: 121-125.

10. Islam SKMA, Hoque MA, Alam MR, Hassan MM and Rahman MA (2006). A Cross- sectional study on production performance of stall fed dairy cattle at Central cattle Breeding Station (CCBS), Savar, Dhaka, Bangladesh. Bangladesh Journal of Veterinary Medicine 4: 61-63.

11. Khair A, Alam MM, Rahman AKMA, Shahiduzzaman, Parvez MS and Chowdhury EH (2014). Prevalence of cryptosporidium in crossbred calves in two selected areas of Bangladesh. Bangladesh Veterinary Journal 12: 185190.

12. Malik S, Verma AK, Kumar A, Gupta MK and Sharma SD (2012). Incidence of calf dirrhoea in cattle and buffalo calves in Uttar Pradesh, India. Asian Journal of Animal and Veterinary Advances 7: 1049-1054.

13. Martin SW, Meek AH and Willeberg P (1987). Veterinary Epidemiology: Principle andMethods. Iowa state University Press, Iowa, USA.

14. Megersa B, Yacob A, Regassa A, Abuna F, Asmare K and Amenu K (2009). Prevalence and incidence rates of calf morbidity and mortality and associated risk factors in smallholder dairy farms in Hawassa, Southern Ethiopia. Ethiopian Veterinary Journal 13: 59-68.

15. NADIS Ltd (2014). National Animal Disease Information Service of UK, Calf Scour-suckler herds. www.nadis.org.uk/ulletins/calf-sucker-herds.aspk.

16. National Livestock Development Policy (2007). Department of Livestock Services, Ministry of Fisheries and Livestock, Bangladesh.

17. Samad MA (2008). A Textbook "Animal Husbandry and Veterinary Science". Volume 2. $1^{\text {st }}$ Pub., LEP. No. 11, BAU Campus, Mymensingh, Bangladesh, p. 1117-1165.

18. Samad MA, Islam MA and Hossain MA (2002). Clinical survey of calf diseases in the district of Mymensingh in Bangladesh. Bangladesh Veterinary Journal 36: 1-5.

19. Shiferaw Y, Yohannes A, Yilma Y, Gebrewold A and Gojjam Y (2002). Dairy husbandry and health management at holleta. Proceeding of the $16^{\text {th }}$ conference of the Ethiopian veterinary association. Addis Ababa, Ethiopia, p. 103-119.

20. Trence O (2001). Management of dairy calves in Holeta, Central Highlands of Ethiopia. MSc Thesis, Faculty of Veterinary Medicine, Addis Ababa university, Debre-Zeit, Ethiopia and Free University of Berlin.

21. Wudu T, Kelay B, Mekonnen HM and TesfuK (2008). Calf morbidity and mortality in smallholder dairy farms in Ada 'aLiben district of Oromia, Ethiopia. Tropical Animal Health Production 40: 369-376. 